\title{
Are nutritionists worried about the epidemic of tumours in laboratory animals?
}

\author{
By F. J. C. RoE, I9 Marryat Road, Wimbledon Common, London SWI9 ${ }_{5}^{B B}$
}

Lacking any basic training in nutrition, I feel like a bull who is about to enter a china shop! The most I can say for myself is that what I lack in knowledge I make up for in prejudices. Of these the strongest is that I cannot understand why most nutritionists seem to be obsessed by the spectre of deficiency diseases whereas in countries such as Britain, over-indulgence in specific ingestible items, or in food generally, causes far more disease than dietary deficiencies.

Thirty years ago, when I started work with Meyer Salaman in the Cancer Research Department of the London Hospital Medical College, we used to buy in commercially compounded diets to feed our rats and mice. Every so often our precious animals, sometimes in large numbers, would unaccountably sicken or die. The possibility that there was something wrong with the diet was always considered, but it transpired that this was never the cause. Under the conventional conditions in which we kept our animals they were prey to a wide spectrum of parasitic, bacterial, fungal and viral diseases. If we had nutritional disease problems in those days we never knew it. Few animals lived to advanced old age when the effects of nutritional imbalance or over-nutrition are most evident, and against the rich background of infectious disease it would have been difficult to identify nutrition-associated lesions. Those who developed diet formulations such as 'Diet $4 \mathrm{IB}$ ' did so using conventional animals that carried numerous parasites and were subject to a variety of infectious diseases.

During the past 20 years, specified pathogen free (SPF) colonies of rats and mice and other laboratory animal species have been developed and outbreaks of serious life-shortening disease have become much less common. Also the variety of diseases that are seen and the numbers of different kinds of internal and external parasites regularly encountered have become less. Laboratory rats and mice live, on average, appreciably longer and it has become possible to study the geriatric diseases of such species. These developments have resulted, inter alia, in Regulatory Bodies concerned with the elimination of cancer hazards from the human environment, being able to require carcinogenicity tests of longer duration.

My special research interests have always been the mechanisms of carcinogenesis and the detection of environmental carcinogens. In the 1950s most of my work involved studies on known potent carcinogens capable of producing tumours within a few months of first exposure in rats or mice. It was perfectly possible to carry out meaningful research using disease-ridden conventional animals with such substances. Problems arose, however, in the I 960 s when I tried to use SPF animals to test previously untested agents for possible weak carcinogenicity. It became increasingly obvious to me that the untreated control $0029-6651 / 81 / 4013^{-4602} \$ 01.00$ (C) I981 The Nutrition Society 
SPF rats and mice that I was using were manifesting an epidemic of tumours and that against this 'dirty background' I was finding it difficult or impossible to carry out meaningful experiments. Another problem was that, although I was using ostensibly the same strains of animals, mean body-weights and the incidence of obesity, sometimes gross, were increasing. At first, I thought that these problems stemmed from the coincidence of three circumstances; (I) more animals were living to an age at which tumours are common, (2) relative inbreeding had favoured the proliferation of oncogenic viruses and (3) those responsible for animal breeding had been selecting for high body-weight and had inadvertently also selected for high spontaneous tumour risk. Later, however, I became more and more uneasy particularly in the case of mice because it was clear to me that the age-standardized risk of development of a variety of tumours in untreated animals was still increasing from one generation to the next.

\section{Ad lib. feeding versus diet restriction}

Enlightenment came in I973 when I heard Dr Mary Tucker describe similar experiences in a breeding unit of Swiss mice at the laboratories of Imperial Chemical Industries Ltd (ICI). This unit was established in $196 \mathrm{I}$ and each year over the next Io years a large sample of mice of both sexes was set aside for lifetime observation. The diet formulation remained the same and every effort was made to avoid genetic drift. The sample cohort of mice born in $196 \mathrm{I}$ were found to have a life-time expectation of developing one or other form of neoplasm of approximately $10 \%$. Successive yearly cohorts, thereafter, exhibited increasing mean body-weight and increasing tumour incidence. Many of the $197 \mathrm{I}$ cohort were grossly obese and the life-time expectation of tumour development had risen eightfold to around $80 \%$.

Suspecting that overnutrition might be a factor Dr Tucker carried out the simple experiment which she and I reported in 1973 (Roe \& Tucker, 1974). The results of this study (Table 1 ) showed three things very strikingly; (1) that mice fed ad lib. developed 6-8 times as many tumours of a variety of different kinds as

Table I. First Tucker study: tumour incidence in groups of forty outbred ICI SPF Swiss male mice"

Feeding regimen...

No. of mice per cage

Amount of food consumed $(\mathrm{g} / \mathrm{d})$

No. of mice with liver tumours

No. of mice with lung tumours

No. of mice with lymphoreticular neoplasms

No. of mice with other neoplasms

Total no. of tumours

$\begin{array}{lc}\text { Ad lib. } & \text { Ad lib. } \\ 5 & \text { I } \\ 5 \cdot 77 & 5 \cdot 77 \\ 8 & 15 \\ 6 & 2 \\ 9 & 11 \\ 0 & 4 \\ 23 & 32\end{array}$

$\begin{array}{cc}\text { Restricted } & \text { Restricted } \\ \text { I } & \text { I } \\ 5 & 4 \\ 2 & \text { I } \\ 0 & \text { I } \\ \text { I } & 2 \\ \text { I } & 0 \\ 4 & 4\end{array}$

"Roe \& Tucker, 1974. 
mice fed according to a restricted regime, and (2) that the extent of the restriction did not seem to matter. Thus $14 \%$ restriction to $5 \mathrm{~g}$ of diet/d compared with the $5.8 \mathrm{~g}$ per day consumed by ad lib. fed mice was just as effective in reducing tumour incidence as $31 \%$ restriction to $4 \mathrm{~g} / \mathrm{d}$. (3) That the kinds of tumour most affected by diet restriction were those that were commonest in the ICI strain, namely liver tumours, lung tumours and lymphoreticular neoplasms, known to be of essentially virus origin.

It seemed that $\mathrm{Dr}$ Tucker had found a way of reducing the $80 \%$ over-all tumour incidence of the $197 \mathrm{I}$ cohort of ICI mice to something like the $10 \%$ incidence level seen in the 196r cohort. More importantly from my viewpoint her experiment drew attention to what to me now seemed obvious. Whereas ad lib. feeding might not be inappropriate for parasite-bearing disease-ridden conventional animals destined to die of intercurrent diseases in their prime or before, it is wholly inappropriate for SPF animals capable of living into old age.

One has only to compare the obese, sluggish and ad lib. fed SPF rats and mice with their smaller, sleaker, healthier, longer-lived restricted-fed SPF counterparts to be quite sure that restricted feeding is the proper procedure. What I cannot understand is why are not professional nutritionists saying this loudly and clearly?

I suspect that there are two main reasons. First, animal nutritionists are mainly concerned with growth and with the evaluation of dietary variables in actively growing animals rather than with the effects of diet on geriatric disease and cancer. Secondly, it is widely thought that following the classical series of experiments in the I 950 s and I 960 s by Tannenbaum and his colleagues on the effects of energy intake on cancer incidence, all the important facts are known and there is no scope for further research. I am sure that this latter assessment is wrong. Tannenbaum was working with conventional animals. The introduction of SPF animals posed the need for a whole new round of basic nutritional research and entirely new questions on the relationship between diet and cancer incidence. This need for new basic research has simply not been met.

Recently three more important sets of results have been published on the effects of diet restriction. Tucker (1979) reported similar results from a further mouse study (Table 2) and Conybeare (I980) using a different strain of SPF mice and two different commercial diets, reported very striking effects of diet restriction on the incidence of benign and malignant tumours generally but especially on the incidences of lung and liver tumours (Tables 3 and 4). In both these studies as in the mouse study reported earlier by Tucker, diet restriction was associated with better survival and despite this the life-time expectation of tumour development was less. However, it is the result of the third of these recently reported studies which intrigues me most. Tucker (1979) compared survival and tumour incidence over a period of two years in a Wistar derived strain of rats. Diet restriction was associated not only with improved survival and reduced tumour incidence generally (Table 5) but also with selective reduction in pituitary tumour incidence from over $30 \%$ to nil in males and from 66 to $38 \%$ in females and in mammary tumour incidence from 34 to $6 \%$ in females (Table 6). 
Table 2. Second Tucker study: effect of diet restriction on tumour incidence in micet

Feeding regimen...
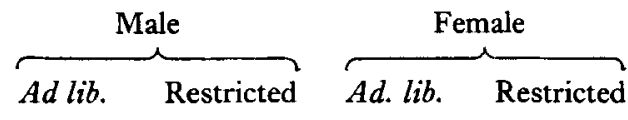

No, of mice initially

Survived for $>30$ months

Crude cumulative incidence of tumour-bearing miceł

Crude total number of tumours

Crude incidence of mice with liver tumours

Crude incidence of mice with pituitary tumours

Crude incidence of mice with lung tumours

Crude incidence of mice with neoplasms of lymph nodes or thymus

$\begin{array}{rcrc}50 & 50 & 50 & 50 \\ 2 & 18^{* * *} & 4 & 18^{* * *} \\ 40 & 26^{* *} & 41 & 23^{* * *} \\ 6 \text { I } & 35^{* * *} & 59 & 31^{* * *} \\ \text { I4 } & 2^{* *} & 2 & 4 \\ \text { I } & 0 & 7 & 0 \\ 8 & 3 & 7 & 3 \\ \text { I0 } & 5 & 17 & 10\end{array}$

"P<0.05, **P<0.01, "**P<0.001.

†Tucker, 1979 .

fi.e. without correction for survival differences.

Table 3. Effect of simple dietary restriction on survival of mice ${ }^{\dagger}$

\begin{tabular}{|c|c|c|c|c|}
\hline \multirow{4}{*}{$\begin{array}{l}\text { Feeding regimen ... } \\
\text { Week o } \\
\text { Week } 83\end{array}$} & \multicolumn{2}{|c|}{ Males } & \multicolumn{2}{|c|}{ Females } \\
\hline & Ad lib. & $\begin{array}{l}\text { Restricted to } \\
75 \% \text { of ad lib. }\end{array}$ & Ad lib. & $\begin{array}{l}\text { Restricted to } \\
75 \% \text { of ad lib. }\end{array}$ \\
\hline & 160 & $\begin{array}{l}160 \\
106\end{array}$ & I60 & 160 \\
\hline & 93 & & & \\
\hline
\end{tabular}

Table 4. Effect of simple dietary restriction on tumour incidence in mice ${ }^{\dagger}$

(Values are no. of mice which developed tumours at any time during the study. There were 160 mice of each sex in each group.)

\begin{tabular}{|c|c|c|c|c|}
\hline \multirow[b]{2}{*}{$\begin{array}{l}\text { Feeding regimen ... } \\
\text { Type of tumour }\end{array}$} & \multicolumn{2}{|c|}{ Males } & \multicolumn{2}{|c|}{ Females } \\
\hline & Ad lib. & $\begin{array}{l}\text { Restricted to } \\
75 \% \text { of ad lib. }\end{array}$ & Ad lib. & $\begin{array}{l}\text { Restricted } \\
75 \% \text { of } a d\end{array}$ \\
\hline Lung & 30 & $19^{*}$ & 24 & $8 * *$ \\
\hline Liver & 47 & $12 * * *$ & 7 & $I^{*}$ \\
\hline Lymphoma & 4 & I & II & $4^{*}$ \\
\hline Other & 8 & 4 & 12 & $4^{*}$ \\
\hline $\begin{array}{l}\text { Any tumour } \\
\text { at any site } \\
\text { Any malignant }\end{array}$ & $7^{1}$ & $3^{6 * \cdots}$ & $5^{\circ}$ & $17^{* *}$ \\
\hline tumour & 17 & $7^{*}$ & 23 & $7^{* *}$ \\
\hline
\end{tabular}


Table 5. Effect of dietary restriction on 'spontaneous' tumour incidence in rats ${ }^{\dagger}$

Feeding regimen...

Food consumption $(\mathrm{g} / \mathrm{d})$

Survival for 2 years $(\%)$

Tumour-bearing animals

before or at 2 years $(\%)$

Mean number of tumours/rat

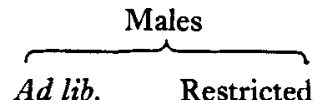

$\overbrace{\text { Ad lib. } \quad \text { Restricted }}^{\text {Females } \ddagger}$

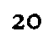

72

15

90

66

0.94

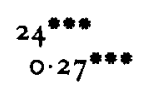

$\begin{array}{ll}1^{*} & \text { I5 } \\ 68 & 88\end{array}$

$82 \quad 5^{6 *}$

I. $18 \quad 0.76^{\text {*n }}$

$" P<0.05, " * P<0.01, * * P<0.001$.

t.Tucker, 1979 .

$\ddagger$ The $a d$ lib. fed females ate less than anticipated and in fact consumed only the same amount daily as the restricted animals. The difference was that the ad lib. fed animals were never faced with an empty food basket.

Table 6. Effect of dietary restriction on incidence of pituitary and mammary tumours in rats ${ }^{\dagger}$

\begin{tabular}{|c|c|c|c|c|}
\hline \multirow[b]{2}{*}{ Feeding regimen ... } & \multicolumn{2}{|c|}{ Males } & \multicolumn{2}{|c|}{ Fernales } \\
\hline & Ad lib. & Restricted & Ad lib. & Restricted \\
\hline $\begin{array}{l}\text { Rats with pituitary } \\
\text { tumours (\%) } \\
\text { Rats with mammary }\end{array}$ & $3^{2}$ & $0^{* * *}$ & 66 & $39^{* *}$ \\
\hline tumours $(\%)$ & o & o & 34 & $6 * * *$ \\
\hline
\end{tabular}

These latter results indicate unequivocally that diet restriction alters the hormonal status of laboratory rats in a beneficial way. Anyone seeing these results for the first time must surely be amazed at the very high incidences of pituitary and mammary tumours in the ad lib. fed groups. And yet these incidences are quite usual for control rats in long-term toxicity studies and cancer researchers are so familiar with such high incidences that they have come to regard them as both 'normal' and 'acceptable'. My plea is that they and nutritionists pause to reflect on these results and ask themselves 'Are animals which are so subject to gross manifestations of serious endocrine abnormality really appropriate models for the investigation of exogenous agents for possible toxicity and carcinogenicity??

\section{Serum prolactin}

In rats there is a relation between serum prolactin levels and mammary tumour risk. Prolactin is released from the pituitary where it is secreted by cells which are easy to mistake for chromophobe cells by pathologists provided only with haematoxylin and eosin-stained sections (Robert \& Hardy, 1975). Hyperplasia of such cells and adenoma formation are seen in high incidence in aged female rats 
which are also subject to high risk of mammary tumour development. Putting two and two together, I deduced that in ad lib.-fed rats, serum prolactin release must be excessive and that diet-restriction tends to correct this. As far as I know no-one has studied the effects of diet-restriction on serum prolactin levels in rats. However, I was able to obtain some results for serum prolactin levels in ad lib.-fed rats which indicate an alarming rise to quite abnormal levels from the age of about 6 months (Table 7). I predict that diet restriction is associated with far less impressive rises with age.

Table 7. Serum prolactin levels in ad lib.-fed Sprague-Dawley rats

\begin{tabular}{|c|c|c|}
\hline \multirow{2}{*}{$\begin{array}{c}\text { Age } \\
\text { (months) }\end{array}$} & \multicolumn{2}{|c|}{$\begin{array}{l}\text { Serum prolactin* } \\
(\mathrm{ng} / \mathrm{ml})\end{array}$} \\
\hline & $\sigma^{\prime}$ & ף \\
\hline 2 & 26 & $2 \mathrm{I}$ \\
\hline 3 & 27 & 37 \\
\hline 4 & 28 & 34 \\
\hline 7 & 35 & 74 \\
\hline I3 & I 28 & 214 \\
\hline 19 & 119 & 345 \\
\hline
\end{tabular}

*Level in non-pregnant women; $20-40 \mathrm{ng} / \mathrm{ml}$.

\section{Hormonal status generally}

Apart from not being a nutritionist, I am also not an endocrinologist, but I have been informed that if one removes the food hopper of a caged animal, it very soon afterwards experiences a rise in serum stress hormone levels. The regular occurrence of such a rise in diet-restricted animals after they have completely consumed their daily ration might well be a more important factor than simple energy restriction. This could explain why in Dr Tucker's first experiment, $14 \%$ restriction had the same effect on tumour incidence as $31 \%$ restriction.

Certainly, although I am quite certain that serum prolactin levels are partly normalized by diet-restriction, I am equally sure that this change is only a marker of a more widespread and profound effect of restriction on hormonal status. Ad lib.fed animals exhibit high incidences of pathological change including tumours in many different endocrine tissues and hormone-dependent tissues other than the pituitary and mammary gland and the tendency is for diet restriction to reduce the incidence of such changes across the board.

\section{The need for other research}

My thesis so far therefore is that laboratory animals maintained on ad lib. feeding regimes manifest numerous abnormalities in endocrine status from the age of about 6 months onwards and are hardly suitable for investigating the chronic pharmacological or toxicological effects of exogenous substances particularly those 
concerned with the endocrine system itself. Diet restriction can reduce the incidence of abnormalities, but in the experiments $I$ have quoted it has not abolished them (see Table 6). There are clearly other aspects of the way in which we maintain animals during long-term laboratory studies which are unsatisfactory. Some of these are probably not nutritional in nature. For instance, life-long enforced celibacy per se might not be a good thing. In humans, we know (MacMahon et al. 1973) that successful pregnancy before the age of 30 reduces subsequent breast cancer risk (Fig. I). Perhaps the same is true for rats. Furthermore, we do not stop short at depriving our laboratory animals of normal sexual fulfilment, but make the situation far worse by housing males and females sufficiently closely that they can smell each other but not touch. No wonder pseudo-pregnancy is rife and pathological changes in the gonads and genital tracts of both males and females are excessively common!

\section{Dietary fat level}

I do not really wish to detract from the force of what I have been saying about the importance of diet restriction by opening a door which permits those obsessed with disease due to dietary deficiency to climb back again onto their favourite hobby horse. However, there is one matter which I must address, namely, the effect of dietary fat on liver tumour incidence.

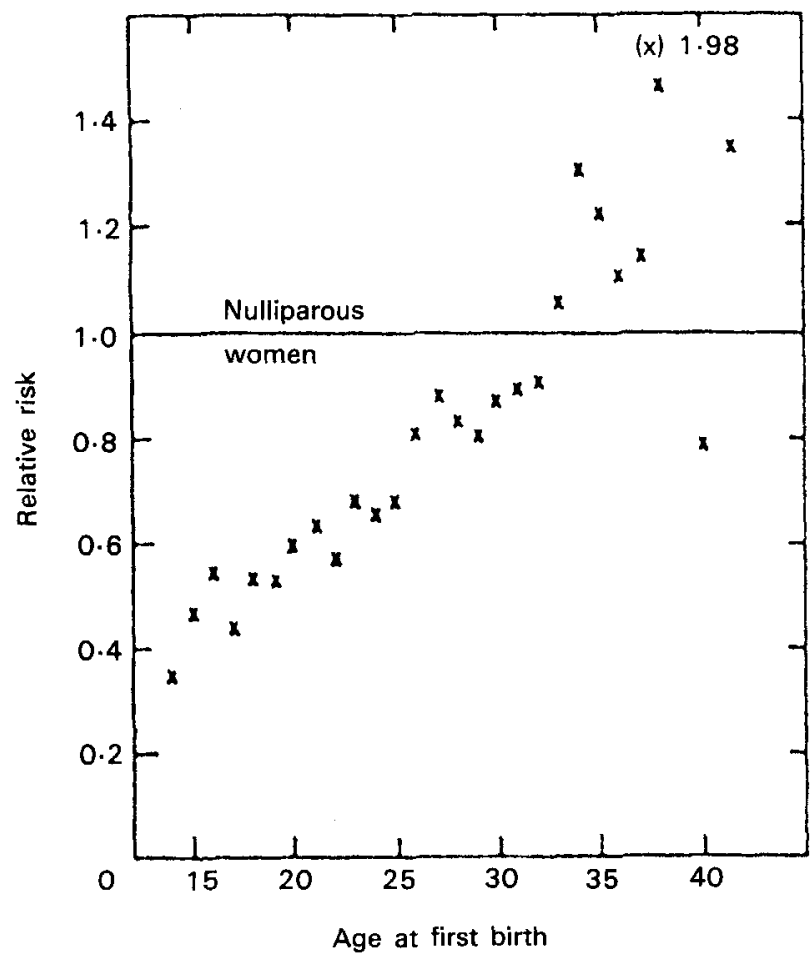

Fig. I. Breast cancer risk according to age at birth of first child. Relative to risk of $1 \cdot 0$ for nulliparous women. (From MacMahon et al. 1973; the author thanks Dr Brian MacMahon and his colleagues for permission to reproduce this figure). 
The successful development of SPF animal facilities depended on the availability of animal diets that were not contaminated with pathogenic micro-organisms or parasites. Pasteurization was one solution but a difficulty with this was that pellets tended to crumble during heating. By incorporating more fat in the formula, crumbling of pellets could be prevented. And so without, as far as I can see, any reference to a nutritionist, laboratory animals began to be fed on diets containing more fat than previously. The pasteurization process added to the costs of all diets and reduced the differential between the price of maintenance and breeding diets. Without giving a thought to the consequences in terms of possible overnutrition, some research establishments chose to use the more expensive diets for all purposes with the result that ancient obese animals found themselves faced with fat-rich, protein-rich, vitamin and mineral-rich diets designed for breeders or young rapidly growing animals. The effect reported by Gellatly (1975) of dietary fat concentration on liver tumour incidence in inbred $\mathrm{C}_{57} \mathrm{BL}$ female mice (Table 8) illustrates dramatically why experimentalists need to take the nutritional requirements of their animals seriously. Furthermore, the finding of Hill et al. (1977) that a high fat diet increases serum prolactin levels in rats suggests that even the effect of fat intake on tumour incidence may be mediated via an alteration of endocrine status.

Table 8. Dietary fat and liver tumours in $C_{57} B L$ female mice*

SS diet with 5\% GNO
$\begin{gathered}\text { Benign or } \\ \text { malignant }\end{gathered}$
SS diet with 10\% GNO
GNO, groundnut oil.
*Gellatly, 1975.

\section{Conclusions}

In my opinion toxicologists and oncologists generally have hitherto paid far too little attention to the dietary needs of the animals they study and even now are negligently unaware of the many serious problems associated with overnutrition that have become increasingly obvious with the development of SPF facilities. It is an unfortunate accident of history that ad lib. feeding is regarded as the norm for laboratory rats and mice. It enabled animal laboratories to be run on 5 -d working week basis without serious criticism from the Home Office fearful that animals might starve. It is now overdue that restricted-feeding be regarded as the norm and as more scientific. But before this can come about, a great deal of serious nutritional research linked with endocrinological research and research on animal husbandry needs to be undertaken. The object of this research would be to define conditions under which laboratory animals may be maintained into old age 
essentially free from artefactual disease due to overfeeding, excessive mineral intake, lack of sexual activity, lack of exercise and lack of the kinds of stress that are associated with life in the wild. At present there is an epidemic of tumours among untreated control animals in long-term toxicity experiments. Nutritionists should know about this and should be actively seeing what they can do to correct the situation.

\section{REFERENCES}

Conybeare, G. (1980). Fd. Cosmet. Toxicol. 18, 65.

Gellatly, J. B. (1975). In Hepatic Neoplasia, p. 77 [W. H. Butler and P. M. Newberne, editors]. Amsterdam: Elsevier Scientific.

Hill, P., Chan, P., Cohen, L., Wynder, E. \& Kuno, K. (1977). Cancer 39, 1820.

MacMahon, B., Cole, P. \& Brown, J. (1973). F. natn. Cancer Inst. 50, 21.

Robert, F. \& Hardy, J. (1975). Arch. Path. 99, 625.

Roe, F. J. C. \& Tucker, M. J. (1974). Proc. Europ. Soc. for the Study of Drug Toxicity, 15, I 71. (Excerpta Medica Internat. Congr. Ser. No. II3).

Tucker, M. J. (1979). Int. F. Cancer 23, 803. 